\title{
Towards a pluralistic understanding of Chinese homeowners: the case of 'ordinary' buyers
}

\author{
Frances Brill ${ }^{\mathrm{a}, *}$, Mike Raco ${ }^{\mathrm{b}}$ \\ ${ }^{a}$ Bartlett School of Planning, UCL, Central House, 14 Upper Woburn Place, London, United Kingdom \\ ${ }^{\mathrm{b}}$ Bartlett School of Planning, UCL, United Kingdom
}

\section{A R T I C L E I N F O}

\section{Keywords:}

Real estate

London

Urban governance

Urban planning

Chinese

Housing

\begin{abstract}
A B S T R A C T
In this paper we address 'ordinary' Chinese buyers in London's residential real estate market. We argue that current academic and policy analysis, particularly of elites, has focused on the higher-end of the market and over-emphasised the detached nature of international buyers. In contrast, building on, but departing from, existing analyses of the multiple classes of Chinese investors evident in London (see Glucksberg, 2016), we reveal the tactics and motivations of buyers with budgets of less than $£ 500,000$. We show that they are motivated by good schools, easy commutes and use similar technologies to mediate and understand the market to local buyers. Such aims and approaches, we argue, show the ordinariness of many Chinese buyers. Underpinning their aims is an aspirational, class-defined desire based on making sacrifices so their children can have a 'normal British life'. This becomes an elective belonging, as they integrate into the norms of London's housing market. In demonstrating how the realities of ordinary buyers contrasts with existing narratives of Chinese investors, we highlight plurality of experiences, strategies and aims of Chinese people buying homes. We argue such an understanding forces us to rethink the form and character of Chinese investment practices in western cities by de-centring London's prime areas and purchasers when analysing property acquisition's internationalisation. In turn this evidences the false binary of local and international demand and shows the complexities hidden behind narratives of international capital.
\end{abstract}

\section{Introduction}

Since the global financial crisis of 2008, much of the development in urban centres such as London has focused on the delivery of relatively standardized forms of housing, typified by larger and denser units that are seen as safe investment spaces targeted by international buyers (Fernandez et al., 2016; Lekander, 2015; Guironnet et al., 2016). For governments and territorial planning systems at multiple scales, such development patterns accentuate acute problems of housing availability and affordability for existing residents and citizens. Cities have therefore sought to introduce measures to limit where and how international investors and buyers can operate, albeit with limited success and in tension with broader economic development policies that often seek to encourage inward investment, both at an individual acquisition level and for development finance.

There has been a particular focus amongst both policy-makers and academic commentators on the role of Chinese investors and buyers in western cities; from those involved in pre-development funding to those who have acquired individual properties. There is a growing concern that broadly-conceived 'Chinese' activities are helping to inflate the cost of housing through increased demand, whilst also shifting supply by encouraging house-builders to focus their attention on the construction of dense, high-rise luxury apartments, rather than the wide range of property types required by citizens. This narrative is evident in a London context, especially in discussions of empty glass towers lining the river, or penthouses that are never used: 'safety deposit boxes in the sky' (see Rees, 2015). Responding to this, the election of Mayor Khan in 2016 was, in part, framed as a campaign that emphasised giving existing city residents 'first dibs' in buying new homes (Sadiq Khan and London Labour, 2016). In other cities, such as Vancouver, property taxes have been explicitly designed to discriminate against Asian investors, who are similarly blamed for the city's increasingly expensive property market. Likewise, in Sydney, dominant narratives of Chinese property investment and elite buying practices have focused on the damaging effects on the city's housing availability and place cohesion (Rogers et al., 2017). The result in many western contexts, as Kan (2017: 36) observes, is 'enlivened sociocultural anxieties' which have 'contributed to the growth of protectionist and xenophobic discourses

\footnotetext{
* Corresponding author.

E-mail address: Frances.brill@ucl.ac.uk (F. Brill).
} 
surrounding issues of housing affordability and insider/outsider relations'. Chinese buyers are viewed as model examples of 'citizens of anywhere', detached from the cities and neighbourhoods in which they nominally reside and in which they play little part as active citizens (Goodhart, 2017).

In this paper we draw on the findings of a research project on the production of residential built environments in London to focus on residential property acquisition by individual homeowners from China. In doing so we challenge a growing orthodoxy in policy framings and academic writing that conflates 'buyers' with 'investors' and 'elites' with 'foreign' actors. We explicitly focus on what we term 'ordinary' buyers to analyse the lower-end of the market: the sub $£ 500,000$ home buyer. In doing so we add to the burgeoning work that seeks to differentiate the complexities of Chinese property acquisition in London (see Glucksberg, 2016). These foci help address two limitations of existing research. First, despite a long history of understanding the role of 'key workers' in urban studies literatures (see Raco, 2008), current analysis tends to either focus on the bottom end of the market experiencing extreme and aggravated evictions in the name of the development of new homes (see Gillespie et al., 2018) or high-end, ultra-wealthy consumption patterns which cause displacement problems, especially in the context of international property acquisition (Atkinson, 2020). Second, analysis has concentrated on central locations within major cities or zones which immediately surround the central area (see Hubbard and Lees, 2018). We argue that in doing so, research has neglected the investment and buying patterns in non-central or high-end locations and ordinary, diverse neighbourhoods across cities. Moreover, it has over-emphasised the detached nature of international buyers, neglecting those who seek to make cities such as London their home, embedding themselves in the everyday life of being a Londoner.

In the first section we address existing analysis of investment into London by Chinese-based firms and individual buyers, arguing that it focuses disproportionately on the higher-end of the market and reinforces binary distinctions between parasitic 'external' actors and territorially-bounded 'residents', whose lives and neighbourhoods are undermined by the presence of the former. We follow this by looking at those with budgets of less than $£ 500,000$, a price more aligned with median house prices in London, to reveal how attention to everyday actions can facilitate a more in-depth engagement with the diversity of buyers who identify as Chinese in London's residential market. We then discuss our methods and methodology before examining the strategies and motivations of lower-end buyers and how these reveal underlying dynamics. In doing so we argue that many Chinese buyers resort to 'ordinary' processes and patterns of homeownership when acquiring their property in London. We argue that far from representing detached and dis-embedded citizens of anywhere, the majority of Chinese buyers engage in a type of what Savage (2014: 50) terms 'elective belonging' in which they are 'culturally engaged and highly vested in their location... with a possessive concern over place'. Moreover, finding a home echoes the experiences of existing home buyers and residents: they face the same issues and use similar approaches to navigate the system. The impacts of elite investment are also negatively experienced by the group of buyers we analyse. Finally, we turn to the consequences of our research and argue that dominant narratives require a re-framing of both what it means to be a resident/outsider in global cities such as London, and are overly concentrated on the transformation of the central areas of cities and the types of housing available, to examine the multiple spaces and places where international capital locates.

\section{Elite (and) Chinese investment in London}

Much of the attention on Chinese property acquisition has focused on the super-wealthy or ultra-high-net-worth individuals (UHNWI), those 'buyers from China and Hong Kong, who have snapped up trophy assets in the City of London and the West End' (Financial Times, 2016 n.p, emphasis added). This focus on Chinese investment and its impact should be contextualised against the broader shift towards understanding the particularities of elite formation especially in cities (see Beaverstock et al., 2004; Friedman and Laurison, 2019; Savage and Williams, 2008). In urban studies, research addressing the attitudes and actions of elites is particularly evident in recent sociological analysis which has exemplified how their presence and effects impact housing markets by reproducing issues of affordability (see Dorling, 2014; Burrows et al., 2017) and changes socio-spatial formations (Atkinson et al., 2017). This work has continued and developed from earlier findings which showed how cities became increasingly segregated, with a separation of elites into enclaves of exclusivity (Atkinson, 2006). Returning to the focus of this paper, more recent contributions have paid particular attention to East Asian investors who have emerged, off the back of domestic economic growth, as increasingly important actors in international investment and consumption, especially of property (Rogers et al., 2015).

Looking to other contexts, as Rogers et al. (2015) shows, the ways in which particular Australian cities are depicted for Asian markets points to the growing influence of brokers or 'translators' (see also Halbert and Rouanet, 2014 on Bangalore's property market). This research stresses the importance of the spatial fix (Rogers and Koh, 2017) chiming with broader narratives on housing's financialization (see Aalbers, 2015), as well as the impact of regulatory reforms (Kan, 2017). Throughout this body of work on the geopolitics of housing investment, what is clear is that irrespective of what or how they have invested (or why), as Forrest et al. (2017) note, there is at minimum, a perception that Chinese investment heavily impacts local housing markets. This sentiment is supported by in-depth qualitative engagement with existing residents, where Rogers et al (2017: 437) demonstrate there are 'high levels of public concern and discontent about foreign investment amongst Sydneysiders, with Chinese investors being a key target of this discontent'. However, this literature, whilst broadly informative in terms of understanding changing property dynamics fails to engage with the ways international buyers can - and do - embed themselves in the local communities. In emphasising detachment from the city and the presence of internationally-owned empty homes there is a homogenisation of international buyers (see for example Atkinson, 2020).

To address this, we follow emerging work that focuses on the nonsuper-elite Asian actors, for example Ho and Atkinson's (2018) analysis of middle-class Hong Kong investors in London. They highlight the ways in which investors sought out 'big fry', or ultra-high-net-worth individuals, and the use of intermediaries. By focusing on Hong Kong investors, their analysis points to the importance of adopting an historical approach - investors from Hong Kong arrived in London in the $1970 \mathrm{~s}$ and were heavily influenced in their strategies by the British occupation of Hong Kong. Doing so not only highlights that this is not a 'new' phenomenon, but also that early investors were motivated by a desire to live in the property. Glucksberg's (2016) ethnographic-based analysis of London's housing crisis sketches out a similar focus on nonUHNWI and draws attention to the importance of differentiating between the agendas and attitudes of foreign investors (beyond just Chinese or Hong Kong investors). She distinguishes between those who 'shore up' investment in high-end areas such as Mayfair and 'middleclass Chinese' who buy property to let out. Going further, she sketches out a typology of buyers in London's high-end market: (1) Buy to invest, who she notes are often from Hong Kong and the Far East who buy flats to then rent out - typically 2 bedroom and new-build. This sort of buyer might commonly be associated with London's intense regeneration agenda more broadly. (2) Buy for business - these actors need to be in London, in some capacity, for their work. These individuals, Glucksberg argues, might be based in Arab states or Russia. (3) Buy for Children, these Glucksberg notes, are people displaced from classic London postcodes who contribute to spatially displaced demand across the wider London region. (4) Buy to leave, properties which are purchased as a means of storing wealth (see also Fernandez et al., 2016).

There are two further important examples of analysing non-elite 
'Chinese' activity in global cities which we take inspiration from. Firstly, Dittgen's (2017) recasting of the so-called 'China in Africa' narrative through a focus on Chinese modernity in Johannesburg. His paper, speaking across the various places where Chinese immigrants have made a home in Johannesburg (from Chinese malls to potential new megaprojects) highlights the persistence and history of Chinese spaces. In doing so it forces to the forefront an analysis of Chinese investment into the urban fabric, the ways in which Chinese actions are organic and 'ordinary' in their new local context (see also Harrison et al., 2012). Such attention to 'normal' urban processes in cities encourages a more thorough engagement with the variety of places, spaces and processes Chinese actors are involved in. Secondly, returning to a London context, Knowles and Burrows' (2017) work on Chinese migrants in London addresses the city as a site to explore migration and therefore focus on Chinese London - deliberately seeking to move past migratory tendencies to look at bodies and instead draw attention to the city-ness of migratory practices. In doing so they conclude that Chinese buyers actively make spaces in cities such as London. Such an understanding encourages our analysis to engage more precisely with the underlying processes and what these show about both the strategies and implications of Chinese property acquisition and its governance in London.

\section{London's housing market: what makes an 'ordinary' buyer and moving out to the suburbs}

In departing from existing analysis by focusing on non-elite actors, we first need to (1) understand the wider context of London's housing market and re-centre voices with 'ordinary' incomes and (2) focus on different spaces and locations - those non-elite - or non-high-end properties and locations, thereby addressing the strong bias in existing research on central London markets and speculative property development.

London's housing market is highly internationalised, receiving annually 'massive injections of overseas capital' (Atkinson, 2019). Many of those who invest in London's property are high net worth individuals with $13.3 \%$ of the world's global elite living in the UK, primarily in London (Atkinson et al., 2016). As such, Savills go as far as to claim that "every buyer in prime London could be described as "international" (Savills, 2013: 3). As Atkinson et al. (2016) note, London's centrality as a global financial and legal centre helps position it as a centre more broadly for wealth accumulation, especially for those from countries such as Russia and China where citizens struggle to protect their assets domestically and therefore look for perceived investment 'safe havens' often in the form of property. For many existing London residents, these flows of investment effectively limit access to the housing market by inflating costs and skewing availability (see also Rolnik, 2019). This is particularly true of the new high-rise blocks which have been built over the last half decade which Atkinson (2019: 3) goes so far as to classify as 'necrotecture' because so many have been (designed to be) left empty. As he argues: 'A distinctive feature of this market is that in many cases units are sold primarily as investments, often 'off-plan', for the purpose of realising future capital gains, occasional sojourns in the city or, in the case of much illicit investment, the concealment and recycling of funds via off-shore investment funds'.

In contrast with such work, we engage with Chinese entry-level buyers, and utilise the concept of 'ordinary' as a lens through which to interrogate the practices of our sample of buyers. This requires engaging with the 'everyday' practices through which they find and make a home in London, and contextualising this against what might be considered 'ordinary' more broadly across the city. The median house price in London is $£ 538,000$ (US $\$ 700,000$ ), with the average first-time buyer having a household income of $£ 79,800$ (US $\$ 103,000$ ). Of London's 32 boroughs, 5 are unaffordable for this group - both traditional high-end central locations such as Chelsea and Kensington, but also newer, more peripheral locations such as Hackney. The outer boroughs remain the most affordable, and whilst it does not follow a strict decrease in value from CBD model, these areas immediately surround central London and form part of the wider London-commuter region. Under current market conditions, the average first-time buyer will have to save for 17 years before they can afford the deposit on a house, with critics pointing out that young Londoners have become 'generation rent' (see McKee et al., 2017 for a fuller discussion). The net result is that only $26 \%$ of those aged between 20 and 39 can expect to own their home by 2025 (PwC, 2016). Of the renters, only $62 \%$ of renters have been in the same property for more than 3 years (ONS, 2019). As such, in our research we focused on buyers that broadly fit this category, or did when they arrived in London (elaborated on further below). They were young(ish), educated professionals with little existing financial capital to rely on.

Despite all these statistics defining what might make an 'ordinary' Londoner, the concept is relatively hard to define. Ordinariness in London is a complex phenomenon, but at the core is finding a place to call home (Carmona and Carmona, 2016). To address this, in this paper we take particular inspiration from Hall's (2007) London Voices London Lives. In it, Hall draws on his academic work from the early 2000s on the experiences of ordinary Londoners, a term left relatively open in the text. Despite this, implicit in whose voice is then recorded and explained is that being a Londoner is full of contradictions. He looks across the city, drawing from interviews across incomes and social classes, demonstrating the breadth of ways people experience their part of London, as well as the wider city region. In doing so he shows how various residents perceive community, racial diversity, transport and local conveniences differently. Yet despite the heterogeneity of people interviewed, there are a number of key themes which emerge. Firstly, the role of transport and easy access to the centre. For many of the respondents, nearby Underground stations play an important role in their life and whilst others (such as middle class 'yuppy' owner-occupiers) argue they would rather get a taxi, they referenced the ease of travelling by bus back home after work. Secondly, those with children talked about having a good environment for raising their children. Again, there was a complexity to this, where people perceived 'safety' differently. However, for most it was about children being able to 'play out'. Relatedly, the third element was access to schools, or rather problems with the schools. Hall quotes parents highlighting the challenges of London schooling and the failures of many state schools. Finally, people talked about leaving the city. As Hall (2007) highlights, drawing on national statistics, the migration of people to and from London is a well-established pattern over the last century.

If Chinese buyers are considered to be more 'ordinary' in their outlooks and positionality, then this opens multiple directions for understanding their engagement with housing markets and the diversity of places that exist across London. Savage (2014: 50), for instance, identifies processes of what he terms 'elective belonging' amongst middle class groups in cities, in which individuals become 'highly vested in their location'. This, he claims, manifests through their efforts to establish connections and forms of social engagement by becoming active citizens and participating in a wide variety of local social and organisational activities. They work hard to establish and claim a 'legitimate local identification' or in Stillerman's (2017: 70) terms, a 'moral ownership of their new communities based on appreciation of their material and symbolic features as well as their decision to put down roots there'. As Savage (2014) argues this process can involve the seizing of local narratives of place and belonging from existing groups, and constitutes an important element in the cultural gentrification of urban areas. In choosing places in which to live, such groups establish top-down forms of belonging and seek to re-shape neighbourhoods in ways that meet their lifestyles and imaginaries of place.

However, much of this work is concerned principally with middle class groups, identified primarily through professional occupations with significant purchasing power. When considered in combination with the cultural positionality and economic resources of ordinary ethnic (and native) Chinese groups, for whom the selection of housing and 
places is shaped by a range of processes, notions of 'elective belonging' become more complex and are likely to take on a variety of forms (Tomaney, 2015). Rather than seeking to re-shape places and communities in their own image, research on socially and culturally diverse residents highlights the importance of local social imaginaries that inmigrants possess, in terms of both a place's communities and their position within them (see Taylor, 2002; Vertovec, 2012). For example, it may be particularly important to seek out and build on legitimate forms of local identification and develop mechanisms of encounter and engagement through which embedded social relations and forms of belonging can be established. Schools and other welfare and community institutions can act as powerful sources for the establishment of such networks.

\section{Researching ordinary Chinese buyers and investors}

The remainder of the paper draws on in-depth research into London's housing market, and reflections from researching Chinese investment and development in the period since the Global Financial Crisis. We interviewed buyers and investors who had acquired London property. We conducted 50 interviews with real estate professionals and people born in mainland China who have purchased property in London and the surrounding area. For the real estate professionals, we interviewed a range of actors, focusing on those who are specifically involved in residential investment and buying, for example Chinese specialist consultants at lead brokerages. Interviews are anonymised and referred to throughout the paper by their respective positions i.e. 'Home Buyer' or 'Developer'.

For the homebuyers, we snowballed from early interviews and existing connections based on previous research on Chinese investment in London. This group was interviewed between February 2019 and January 2020, often on multiple occasions and with follow-up emails and calls. We targeted people who have residence in the UK, had purchased their property since 2008 and were what LOREC (2015) call 'entry level buyers': those with budgets up to $£ 500,000$, whose numbers are expected to increase by $60 \%$ over the next ten years. This is not to say that the group was homogenous, indeed their ages ranged from over 50 to the 25-30 age category; they were born in different parts of China and had very different connections to London. This reflects that we sought out interviewees with mixed motivations for moving to London in the first place to reflect the diversity of reasons outlined in interviews with real estate professionals. Our interviewees had often arrived in London, or the UK, as part of the New Labour higher education policies in the early 2000s that encouraged long term migration following graduation. Indeed, interviewees often explained how their early experiences with the UK state were positive as migrants, because of the receptivity of the higher education system. For more recent arrivals, higher education has also been the main motivator for moving to the UK and to London and this provided an entry point to begin conversation: a shared experience of the UK higher education system. Such individuals are part of the wider internationalisation of higher education and this inevitably influences their experiences (see Lomer, 2018 for a full discussion). Pertinent for this paper are the aspirational desires which underpinned their relocation in the first place and their valuing of education, which emerged as a key theme during interviews and is elaborated on below.

Our interviewees destabilised the category of international buyer as is used in academic discussions, since they promoted a self-identification that straddled being part of 'ordinary' London and still having a deep sense of being 'Chinese', throughout our interviews. For many, their sense of being Chinese was rooted in where they were born, their racial identity, their mother tongue, and familial and sometimes commercial links with China. However, they were also adamant that they were from London in the sense that they had sought to integrate, settle and create families in the city and understood the city as their home. Our position as white academic researchers therefore undoubtedly influenced our interviews. In early discussions with real estate professionals, our shared understanding of real estate markets and jargon, as well as longer term connections from previous research projects, enabled easy conversation and allowed us to speak more freely. However, in some cases there were language barriers and we relied on a translator, as such conversation was slower than might be expected in interviews and there were moments of confusion. We tried to make transparent the research process, especially for those less familiar with academic work (see McDowell, 1992). However, our position as academics undoubtedly created a power imbalance where we had the 'final say' over the interpretation of the interview (Gilbert, 1994; McLafferty, 1995). To mitigate this and attempt to create bridges across the cultural divides we were as open as possible and in doing so we were able to share our mutual valuing of research and education (a theme throughout our interviews) which provided a platform to begin conversations and find the necessary common ground to establish a better rapport.

In the next section we divide the discussion into three parts. The first focuses on the core motivations and strategies used by respondents to buy residential property in London to demonstrate their actions in relation to a sense of elective belonging and an attachment to the city. We draw on our interviews to assess the types of practices involved in selecting properties and neighbourhoods and the factors that influence their decisions, especially schooling. Again, the analysis differs from studies of the private school-driven decisions of UHNWI Chinese buyers and instead indicates the importance of the state education system and the desire of buyers to use their house purchases to access their schools of choice. Our second section then explores the idea of elective belonging in greater depth, addressing attitudes towards betterment and future prospects, particularly in relation to children and views of 'integration'. The first two sections therefore point to the ways in which buyers embed themselves in places, in this case in London. They are followed by a third section that reflects on the wider consequences of these trends for understandings of London's housing market and the ways in which it is governed and regulated.

\section{5. 'For a better life - To give my child a better education': A plurality of motivations and strategies for buying in London}

Interviewees reflected on their key motivations and strategies in looking for and finding a home. Here we outline what these were and how they are best conceptualised as 'ordinary' practices, that differ little from those of other buyers in the sub-prime London market, to reveal the plurality of strategies contained within the realities of 'Chinese buyers'. Specifically, we highlight the use of particular 'normal' technologies such as Zoopla, the way buyers spoke about a desire to find good schools for their children and the need to work with a constrained budget to find a 'good home' within a commutable distance of central London.

In a similar vein to the ways in which existing analysis has highlighted the role of brokers and translators in understanding markets for both investors (see Halbert and Rouanet, 2014; Brill, 2018) and when buying an individual property (see Ho and Atkinson, 2018), in our research we found that interviewees also sought to better understand local property market dynamics. However, in contrast to their more elite peers using bespoke services, our interviewees noted that where possible they and others they knew from mainland China sought to use Zoopla and Right Move - in much the same way a domestic property buyer might. Zoopla, Rightmove and other platforms play an increasing part in understanding housing markets both for consumers and the academic community, since such platforms are the primary means by which people find properties to buy and rent in London (see Birkin, 2019). Their role for Chinese buyers was re-emphasised by interviews with brokers who specialise in Chinese investment who highlighted that their role focused on "higher-end acquisition" and broader 'investment' in the development stages of a project (Chinese specialist property 
consultant, 2019). In this respect, in contrast to the ways in which Ho and Atkinson (2018) emphasise the Chinese-Chinese interactions in property acquisition, our interviews with those who have settled in the UK pointed to the 'normal' or 'ordinary' practices adopted by Chinese buyers which often centred on interacting with, acting in similar ways to and engaging with other 'Londoners'. They are subsumed into the wider system: Right Move currently reports 127.5 million visits per month, Zoopla 50 million - they have become ubiquitous forces in property searches for most British buyers. Their use is part of the ways in which data is reconfiguring the city and how the politics of finding a home - or any other relation making - through data use and generation (since the use of these sites generates as well as uses data) has become a critical facet of capitalist urban production (Simone, 2018).

The use of UK-based portals is of course shaped by the degree to which home buyers are already integrated into particular cultures in the UK and whether their language is sufficient: "if their English is good enough, they'll go to Zoopla and Right Move directly. If not - a Chinese agent" (Home buyer 2, 2019). Therefore, there remains a role for those capable of translating. However, in contrast to the dominance of these intermediary actors in commercial property or with UHNWIs, with ordinary Chinese buyers they are engaged out of necessity. When prompted to explain how these actors work, one interviewee described the process of enlisting a Chinese agent and the simplicity of the process - "they will ask several questions - buying for living or for investment? Where is your money now? What currency?". In these prodding questions the advisors are seeking to establish whether the buyers are 'serious' and the extent to which they have sufficient capital to navigate the challenges of mortgage brokering in the UK (discussed further below).

The second key feature when looking for property is proximity to top-rated state schools, as one interviewee explained: "For myself, in China, [we are a] very normal family and I'm looking for a future". Interviewees highlighted the importance of educational rigour and quality, especially as their families grew. This, in part, reflects the age of our interviewees and the life stage they are at: they have recently purchased property and many reflected that this was part of a settling process. In our first interview, with a property consultant who relocated his family to London just over ten years ago, he recalled that for him and other Chinese mainlanders he knew, education drove their decision making: "they want to live near good schools". Whilst images of London's more prestigious private schools might dominate perceptions of Chinese students in the UK and indeed we found images of many of them in the Mandarin literature sent to potential buyers in China (see Barratt's Homes, 2016), in our fieldwork with lower income buyers we found people were drawn to good state schools and grammar schools ${ }^{1}$. Interviewees knew the statistics and league table results of 'ordinary' schools across London, including its suburbs. This was often reinforced by their own experiences in British education - particularly university experiences. As one interviewee reflected on his motivations for moving to the UK "for a degree, for a promotion, for a better life - to give my child a better education". Supporting Rogers and Koh (2017), who highlight the importance of education as an alternative narrative to the dominant 'spatial fix', in our work too we see a similar pattern in shaping the way Chinese actors searched for a home. As the interviewee went on to generalise "the most attractive for Chinese families to come to the UK is the education system... this country still has a lot of public schools... the reputation and quality of the education is enough" to draw people to relocate their lives from China to the UK, even for lower income or 'entry level' buyers. In this way we see how in contrast to high-end private schools'

\footnotetext{
${ }^{1}$ Grammar schools are state-funded schools that are able to select their own pupils on the grounds of academic entry from the age of 11 onwards. In most of England they were abolished in 1974 and replaced by Comprehensive, nonselective schools, but owing to local variations in legal status and a failure to follow up on the existing legislation, those in London's outer suburbs and some counties surrounding London, were able to maintain their selective systems.
}

impact or access to elite universities, their actions mimic 'traditional' or 'local' actions: they are seeking to make a home within the catchment area of a good school. Moreover, they had worked hard to understand the details of the education system and were able to recall exact statistics "there are 164 grammar schools in this country - we wish to give a child a better education".

Building on this, and the role of 'normal' neighbourhood characteristics, interviewees spoke of many 'ordinary' characteristics. One interviewee, reflecting on the process of settling in London spoke about how, with a budget of "just over $£ 200,000$ " he first looked for a home in the Docklands in London - "because it's cheaper", an area which whilst less central, he considered well-enough connected to key areas for his professional development. As his family expanded, he explained that his priorities shifted, with three children and his eldest son commuting 2 hours each way to a good (state) selective school, he wanted to relocate to be nearer the school. Here he began to explain the rationale for picking the exact location with a focus on rail accessibility: "by train it is 27 min to Charing Cross, 39 min to Victoria, 37 to Cannon Street". His explanations were rooted in ordinary practicalities such as these: one third of British buyers cite 'being close to work' as the most important consideration when buying their home (Santander, 2015). For British buyers, the role of proximity is exacerbated by a need to be located near to good infrastructure and public transport - the second most important factor for UK home buyers (ibid.). As such our interviewee's explanations for picking a place become almost banal - completely 'normal' - in the context of what people more broadly as Londoners are looking for in a home.

\section{6. 'I'm looking for a future here': underlying desires and alternative aims}

In this section we show how the motivations and characteristics of Chinese buyers above are shaped by broader patterns, specifically the class differentials and sense of sacrifice embodied by the experience of relocating to 'ordinary' London for the sake of children, and the challenges of acquiring property. This we argue demonstrates their practices of 'elective belonging' (Savage et al., 2004) as buyers try to locate themselves in local communities and London as a whole. In this regard our analysis demonstrates, in contrast to dominant discussions in academia, the ways in which international buyers, particularly Chinese buyers, are not detached from cities but can become embedded, electing to be a Londoner. In turn this speaks to the ways in which activities beyond financial gain shape international investment and property acquisition. Moreover, in drawing attention to these desires we reveal the plurality of aims within the category of 'Chinese buyers' in London.

Overall the actions of buyers were rooted in a sense of trying to become part of London - to integrate their lives into the systems of the UK. As one interviewee reflected "for myself, in China, I come from a very normal family - I'm looking for a future here - for a very rich class, their life is still in China". Here, he reflected that the class or income differences between him and the elites typically depicted or analysed in research on Chinese investment meant he had a different approach to acquiring property. This class difference is essential in understanding how ordinary Chinese buyers relate more broadly to the London housing market, reflecting that they mostly have a budget of sub $£ 500,000$, they sit firmly around the median house price across London. Many of their actions can be understood as rooted in particular forms of aspiration: they were acting on a desire to increase their children's educational capital. Moreover, this was depicted as a sacrifice orientated towards providing for their children, as one interviewee explained about others moving from mainland China: "they want their money out. They want their children out" and therefore exchanging their life in China for a more ordinary, British life. This also includes the negativities of being a Londoner too though: the role of the private rental sector and the challenges of obtaining a mortgage. In this regard the Chinese buyers 
we interviewed were less 'citizens of nowhere' or everywhere, and instead considered themselves, and actively aligned their experiences to, other Londoners.

Importantly, and echoing broader critiques of London's housing market, interviewees highlighted how expensive housing costs were/ are in London, and therefore the difficulties of trying to raise sufficient funds for a mortgage formed a core component of how or where people chose to buy. In doing so they reflected how they are part of the community of those who struggle with housing affordability across London. Many explained that at first they often rented, trying to understand the market, but also because they were constrained by a lack of deposit for a mortgage. As one interviewee elaborated: "for Chinese people in the UK, they rent properties", this process is often through internal community networks where they find their property "sometimes informally" because there's a perception that they "don't need formal contracts". Whilst this, the interviewee acknowledged, meant people often did not have "sufficient protection", an informal arrangement between Chinese migrants often formed a first point of entry into the housing system. As they established their life more firmly, frequently moving locations before settling, the homeownership aspirations often referred to as part of the British 'psyche' (see McElroy, 2017) became embedded in their housing strategy. Such an approach stands in sharp contrast to existing analysis of UHNWI and demonstrates the plurality of experiences within the Chinese community of London home buyers and occupiers, and the necessity of understanding how each group experiences the precarity and challenges of London.

Despite their homeownership aspirations, interviewees reflected that it was (and remains for others) often challenging to save for a mortgage, a well-reported phenomenon amongst first-time British buyers. This was exacerbated by their often-uncertain immigration statuses which compound the mortgage accessibility issues, as one specialist consultant explained: in the "first year people rent because they can't get a mortgage. They may buy in 3 years - check the children in the school. They're not just looking for a house, they're looking for settlement'. Buying their (London) home was therefore also part of an ingrained societal expectation around homeownership that has filtered out beyond 'locals'. In this regard many 'ordinary' Chinese buyers were subsumed by the same issues as other Londoners - the challenges of finding stable rental proprieties, high rents and their impact on saving for a deposit and the uncertainties of the UK's relatively un-regulated rental sector. They too have suffered from the negative consequences of investments by and for UHNWIs, some of whom originate from mainland China.

It is also necessary to look more broadly at the role of the house as an asset, to understand 'ordinary' Chinese buyers. As is well-established, houses form the primary wealth base for most people in the UK with housing assets underpinning what Crouch (2011) terms 'privatised Keynesianism' or the ability of individuals to use their own means to support their social reproduction. This is also true for many of the Chinese buyers, as one home buyer explained "it is not really purely for investment", but rather it is about the steady acquisition of equity in a property for long term financial and housing security, as with a domestic buyer. As such, for these Chinese buyers their property acquisition is re-centred around use value, rather than exchange value, with capital gains in the long-run part of the broader wealth development of a home-owning democracy - rather than as a specific strategy to protect or increase their wealth. This demonstrates not just the plurality of experiences and strategies, but also of aims.

\section{Consequences for the wider region and governance}

This emphasis on the ordinary dimensions of how lower-income Chinese buyers find and purchase a house has consequences for the governance of London's housing market. In the first instance it decentres the core high-end of London's property market and contributes to a greater understanding of how the wider London region relates to the central areas in terms of attracting international investment. Secondly, it shapes how housing and planning policy attempting to alleviate housing pressures can - and should - see 'international' investors.

London is a polycentric city and the consequence of understanding ordinary Chinese buyers acquiring homes is a de-centring of the analytical gaze away from the 'higher-end' or premium locations when discussing international investment and a recognition of the broader region in London's internationalised housing market. As one advisor interviewed highlighted: "they [ordinary, non-elite Chinese buyers] want to live on the outskirts of London", he went on to draw on examples from Surrey and Kent - positioning the counties that surround London as part of the wider London housing system. In turn, this is important in the context of wider trends in real estate development across the South East of England. One developer interviewed remarked that after the 2008 financial crash many housebuilders moved "into the centre of London, and out of the regions", and he attributed this shift in strategy to a desire to develop new build properties, often for an international crowd, or for first time buyers. At the same time, since the introduction of GDPR legislation ${ }^{2}$ many housebuilders have lost their international client lists as individuals did not re-subscribe after the change in legislation - "they've gone from 200,000 to almost none" which has forced them to change their business model. Part of that will be a shift back to the regions and to outer London, exacerbated by the land value increases in London which for one developer meant he could "no longer make the numbers work" to develop sites. As such, looking forward, developing in the regional markets, both in terms of non-London and the wider London region, will become a more important part of their business strategy. This decentralisation may well be met and enjoyed by the ordinary Chinese buyers since for Chinese buyers, even those with lower budgets, there's an aim to have what one homebuyer made clear: "a new build, a new apartment or house".

What is important in this regard is to understand how the broader shifts are influencing the ways in which different demands in the local market are - or will be - catered for. In contrast to the narratives of 'safety deposit boxes in the sky' (see Rees, 2015), which are assumed to be created to cater for buy to leave UHNWIs and investors and in very central London, the ordinary buyers are instead demanding property in the peripheries. Whilst access to the centre remains at the core of understanding the relocation to the suburbs, there remain other factors which help reveal the ways in which outer London is evolving as part of the wider internationalisation of the city's housing stock.

This combination of changes, and the underlying motivations of Chinese buyers, forces us to reconsider what (or where) is internationalised in real estate development in London - and what the different patterns of investment and consumption mean for understanding the 'geopolitics of real estate development' (see Rogers et al., 2015). This in turn impacts the ways in which London's property market might be governed. As Knowles and Burrows (2017) argue, the increasing number of Chinese applications for UK visas and involvement in the property market has deeply intertwined UK government policy and the (somewhat hidden) dynamics of Chinese growth. They note that for the most part Chinese migrants are positioned as a 'small, successful and ambiguously racialised population, attributes which exclude them [...] [from the 'immigrant problem' framework of both government policy and of much of the social sciences' (Knowles and Burrows, 2017). This draws attention to an important element of understanding more comprehensively the motivations and strategies of ordinary Chinese

\footnotetext{
${ }^{2}$ GDPR refers to the General Data Protection Regulation that took effect from May 2018. The GDPR requires all businesses across the EU to establish Data Management Plans in order to protect the privacy of data providers. The effect on some property businesses is that existing subscribers to their various marketing activities need to actively re-subscribe to lists, otherwise their data is deleted and firms are no longer permitted to contact them.
} 
investors - their relationship with the 'immigration' process and the definition of what it means to be a Londoner.

This is particularly the case given that the growth in attention to international investment or the 'geopolitics' of real estate investment (see Rogers et al., 2015) has highlighted the impact on local citizens' capacities to afford a home - both buying and renting - and has therefore led to increased policy scrutiny. This has been exacerbated by the wider context of a failing housing system which is particularly entrenched in the 'engine of growth' regions of London and the South-east (Hincks et al., 2013). Whilst the city has experienced disproportionate growth, compared to the rest of the UK, wages still lag far behind rents and housing costs. As such, housing forms a core political agenda in the city and wider region and underpinned the current Mayor, Sadiq Khan's, election manifesto where he promised to correct the housing system's failures. Pivotal in this was his 'Homes for Londoners' agenda (see Mayor of London, 2016). This policy approach aims to address the housing crisis in London by supporting councils, housing associations and developers in the delivery of affordable housing. Whilst the policy agenda is not explicit about exactly who is included as a 'Londoner', the existing emphasis in everyday discourses that differentiates between Chinese (and other forms of international) capital and 'local' capital creates a false dichotomy around how the housing system is experienced. Those working on the Homes for Londoners agenda the Home noted in our interviews that it had been relatively ineffective (Consultant 2, 2020). That said, for would-be buyers, its greatest strength is its portal for finding affordable homes. On the website, individuals can input their housing needs and see what meets their requirements. However, since it is just a compilation of other sources, the Mayor and Greater London Authority have no control over the eligibility requirements. Instead these are chosen by the housing associations, local authorities and developers who are selling the homes. In this regard, even with a great appreciation of how ordinary buyers - local or international - fit within the system, the mayor currently still has little control. Ultimately, if London is to be truly 'open for business' then there is a need to recognise the diversity of incomes and corresponding housing capacities of a wider range of demographics, rather than differentiating based on a simplified understanding of how and why Chinese buyers acquire property .

\section{Conclusions}

This paper argues that existing analysis of Chinese homebuyers in London is limited and misses an important, growing, dimension of the sub-market: lower-income, sub- $£ 500,000$ buyers. Following commercial analysis (see LOREC, 2018), we demonstrate that international buyers, particularly Chinese buyers, are not solely concentrated on the higher-end of the markets, but rather that they participate in the full range of the housing system in London. We unpack the pluralities hidden behind the category of 'Chinese buyers' to show the ways nonUHNWI engage with the market - their motivations around being close to schools and easy commutes, arguably very 'ordinary' considerations. In terms of how they go about finding homes, findings show that they use mainstream portals where possible, and that the 'Chinese-Chinese' interaction identified in the literature (see Ho and Atkinson, 2018) is less pronounced at the lower-end. Despite this, there are Chinese-Chinese interactions, but these are informal and centre on gaining an understanding of the market, often through short-term rentals. As such, by revealing their strategies and approaches to house acquisition we show how their actions are demonstrably 'normal' or 'ordinary', and as such just part of the everyday experience of navigating the challenges of London's housing system. By moving past a limited engagement with Chinese buyers and seeing how they are subsumed by similar pressures and arguably respond in a comparable way to 'British buyers' with similar budgets, we show the ways in which the emphasis on elite purchasers has skewed analysis and therefore contributed to the continuation of a limited understanding of who can be a suburbanite through a narrow vision of where Chinese buyers are found.

Re-positioning (some) Chinese buyers in this way sheds light on the shared experiences across nationalities: the challenges of navigating a poorly regulated private rental sector and raising sufficient capital for a mortgage deposit. This helps re-shape the understanding of international dimensions of the London region's housing market and repositions (some) Chinese buyers as people impacted by the system's failures, rather than as implicated in the problems. In demonstrating the plurality of Chinese buyers we show how ordinary Chinese buyers experience the same frustrations as 'locals'. Moving past this false dichotomy casts a different light on the perceived 'problems' of international investment, encouraging, we would argue, a more thorough engagement with the different classes, motivations and strategies of actors overall, rather than a differentiation based on place of birth. Moreover, as evidenced in our research many internationally born buyers face the same difficulties with property acquisition and indeed the role of UHNWI impact their housing costs too.

This, in turn, we argue forces a reconceptualization of Chinese buyers that moves past what we consider a misconceived binary between local and global buyers in policy formation and academic discussions. In academic debates emphasis on safety deposit boxes and empty homes owned by a detached super-elite has failed to engage with the ways in which many international buyers become embedded and ultimately part of cities like London. Understandings of international investment in London's property market have too frequently focused on central locations and the impact in more elite markets, doing so leads to an analysis that is detached from the realities of many people's lived experiences - those trying to make a home in London. Moreover, this research reinforces the idea that decisions are based on financial motivations, underplaying the important role evidenced in the practices of elective belonging highlighted here. The assimilation process of integrating into London's property market, as narrated by buyers during our fieldwork, strongly echoes the experiences of 'locals'. As such, we argue that the current focus on high-end creates a false binary between international and local capital and the differential experiences. Instead, we would suggest that a move away from isolating the ethnicity or country of origin of the capital and instead focusing on the motivations and aims of the occupiers provides a more comprehensive understanding of the impact on development demand.

In a policy context, whilst the Home for Londoners is not explicit in its exclusion of ordinary Chinese buyers, the focus on 'Londoners' without a well-conceived understanding of how newcomers integrate into the market makes outsiders of those who experience the same housing difficulties - the problems of saving in the context of an inflated rental market and the difficulties of affording such high prices. This stands in strong contrast to existing narratives on international capital seeking a 'spatial fix' as the dominant way of understanding how Chinese house or flat buyers find property in global cities. Using this conversation as a starting point, in this paper we argue that a more thorough engagement with such buyers reveals new lines of enquiry for understanding international capital's place in real estate, and helps elucidate the importance of de-centring the focus on elite people and places that dominate existing analyses of Chinese investments in global cities.

\section{CRediT authorship contribution statement}

Frances Brill: data collection, data analysis, writing - original draft preparation. Mike Raco: data collection, data analysis, writing - developing, reviewing and editing.

\section{Declaration of Competing Interest}

The authors declare that they have no known competing financial interests or personal relationships that could have appeared to influence the work reported in this paper. 


\section{Acknowledgements}

We would like to thank the WHIG team for their comments on an earlier draft. The research for this paper was funded by ESRC ORA project ES/S015078/1.

\section{Appendix A. Supplementary material}

Supplementary data to this article can be found online at https:// doi.org/10.1016/j.geoforum.2020.09.017.

\section{References}

Aalbers, M.B., 2015. The Financialization of Housing: A Political Economy Approach Routledge.

Atkinson, R., 2019. Necrotecture: lifeless dwellings and London's super-rich. Int. J. Urban Reg. Res. 43, 2-13. https://doi.org/10.1111/1468-2427.12707.

Atkinson, R., 2006. Padding the bunker: strategies of middle-class disaffiliation and colonisation in the city. Urban Stud. 43 (4), 819-832. https://doi.org/10.1080/ 00420980600597806.

Atkinson, R. (2020) Alpha City How London Was Captured by the Super-Rich Verso 9781788737975 .

Atkinson, R., Parker, S., Burrows, R., 2017. Elite formation, power and space in contemporary London. Theory, Culture Soc. 34 (5-6), 179-200. https://doi.org/10. 1177/0263276417717792.

Atkinson, R., Burrows, Roger, Glucksberg, L. Ho, H.K., Knowles, C., Rhodes, D., Webber, R., 2016. International Flows of Capital into London Property' SPERI (Sheffield Political Economy Research Institute) Global Political Economy Brief.

Beaverstock, J.V., Hubbard, P., Rennie Short, J., 2004. Getting away with it? Exposing the geographies of the super-rich. Geoforum 35 (4), 401-407. https://doi.org/10.1016/j. geoforum.2004.03.001.

Birkin, M., 2019. Spatial data analytics of mobility with consumer data. J. Transp. Geogr. 76, 245-253. https://doi.org/10.1016/j.jtrangeo.2018.04.012.

Brill, F., 2018. Playing the game: An international comparison of real estate developers in Modderfontein Johannesburg and London's Royal Docks. Geoforum. Epub ahead of print 5 June 2018, https://doi.org/10.1016/j.geoforum.2018.05.015.

Burrows, R., Webber, R., Atkinson, R., 2017. Welcome to 'Pikettyville'? Mapping London's alpha territories. Sociol. Rev. 65 (2), 184-201. https://doi.org/10.1111/ 1467-954X.12375.

Carmona, M. Carmona, M.P., 2016. Extraordinary ordinariness, an outsider's perspective on place and placelessness in the Japanese City. In: Freestone, R., Liu, E. (Eds.), Place and ffacelessness Revisited. Abingdon, Rutledge.

Crouch, C., 2011. The Strange Non-Death of Neoliberalism. Polity Press, Cambridge.

Dittgen, R., 2017. Features of modernity, development and 'orientalism': reading Johannesburg through its 'Chinese' urban spaces. J. Southern African Stud. 43 (5), 979-996. https://doi.org/10.1080/03057070.2017.1332899.

Dorling, D., 2014. All That Is Solid: How the Great Housing Disaster Defines Our Times, and What We Can Do About It. Penguin UK.

Fernandez, R., Hofman, A., Aalbers, M.B., 2016. London and New York as a safe deposit box for the transnational wealth elite. Environ. Plan. A: Econ. Space 48 (12), 2443-2461. https://doi.org/10.1177/0308518X16659479.

Forrest, R., Koh, S.Y., Wissink, B., 2017. Cities and the Super-Rich: Real Estate, Elite Practices and Urban Political Economies. Palgrave Macmillan, New York, United States. Available at: http://ebookcentral.proquest.com/lib/ucl/detail.action?docID = 4814214 (accessed 27 August 2019).

Friedman, S., Laurison, D., 2019. The Class Ceiling: Why It Pays to Be Privileged. Policy Press.

Gilbert, M.R., 1994. The politics of location: doing feminist research 'at home' Professional Geogr. 46, 90-96.

Gillespie, T., Hardy, K., Watt, P., 2018. Austerity urbanism and Olympic counter-legacies: gendering, defending and expanding the urban commons in East London. Environ. Plan. D: Soc. Space 36 (5), 812-830. https://doi.org/10.1177/0263775817753844.

Glucksberg, L., 2016. A view from the top. City 20 (2), 238-255. https://doi.org/10. $1080 / 13604813.2016 .1143686$.

Goodhart, 2017. The Road to Somewhere: the Populist Revolt and the Future of Politics. Hurst Publishers.

Guironnet, A., Attuyer, K., Halbert, L., 2016. Building cities on financial assets: the financialisation of property markets and its implications for city governments in the Paris city-region. Urban Stud. 53 (7), 1442-1464. https://doi.org/10.1177/ 0042098015576474.

Halbert, L., Rouanet, H., 2014. Filtering risk away: global finance capital, transcalar territorial networks and the (un)making of city-regions: an analysis of business property development in Bangalore, India. Regional Stud. 48 (3), 471-484. https:// doi.org/10.1080/00343404.2013.779658.
Hall, P., 2007 London Voice London Lives: Tales from a working Capital Policy Press. Harrison, P., Moyo, K., Yang, Y., 2012. Strategy and tactics: Chinese immigrants and diasporic spaces in Johannesburg, South Africa. J. Southern African Stud. 38 (4), 899-925. https://doi.org/10.1080/03057070.2012.741013.

Ho, H.K., Atkinson, R., 2018. Looking for big 'fry': The motives and methods of middleclass international property investors. Urban Stud. 55 (9), 2040-2056. https://doi. org/10.1177/0042098017702826.

Hubbard, P., Lees, L., 2018. The right to community? City 22 (1), 8-25. https://doi.org/ $10.1080 / 13604813.2018 .1432178$.

Kan, K., 2017. The (geo)politics of land and foreign real estate investment in China: the case of Hong Kong FDI. Int. J. Housing Policy 17 (1), 35-55. https://doi.org/10. 1080/14616718.2016.1248607.

Knowles, C., Burrows, R., Reimagining Chinese London, 2017. In: Burdett, R., Hall, S. (Eds.), The SAGE Handbook of the 21st Century City. Sage, London, pp. 87-103.

Lekander, J., 2015. Real estate portfolio construction for a multi-asset portfolio. J. Property Invest. Finance 33 (6), 548-573. https://doi.org/10.1108/JPIF-02-20150013.

Lomer, S., 2018. UK policy discourses and international student mobility: the deterrence and subjectification of international students. Global., Soc. Educat. 16 (3), 308-324. https://doi.org/10.1080/14767724.2017.1414584.

Mayor of London, 2016. 'Homes for Londoners: Affordable Homes Programme 2016 -2021 Funding Guidance' available at: https://www.london.gov.uk/sites/default/ files/homesforlondoners-affordablehomesprogrammefundingguidance.pdf.

McDowell, L., 1992. Valid games? A response to Erica Schoenberger. Professional Geogr. 44, $212 \pm 14$.

McElroy, R., 2017. Mediating home in an age of austerity: the values of British property television. Eur. J. Cultural Stud. 20 (5), 525-542. https://doi.org/10.1177/ 1367549417701758.

Mckee, K., Moore, T., Soaita, A., 2017. 'Generation rent' and the fallacy of choice. Int. J. Urban Regional Res. 41(2), 318-333. https://doi.org/10.1111/1468-2427.12445.

McLafferty, S.L., 1995. Counting for Women. Professional Geogr. 47, 436-442. https:// doi.org/10.1111/j.0033-0124.1995.00436.x.

ONS, 2019. UK Private Rented Sector: 2018 available at: https://www.ons.gov.uk/ economy/inflationandpriceindices/articles/ukprivaterentedsector/2018.

PwC, 2016. UK Housing Market Outlook available at: https://www.google.com/search? client $=$ safari\&rls $=$ en\&q $=26 \% 25+$ of + those + aged + between $+20+$ and $+39+$ can + expect + to + own + their + home + by $+2025+($ PwC, +2016$) . \&$ ie $=$ UTF $8 \& 0 e=$ UTF- 8

Raco, M., 2008. Key worker housing, welfare reform and the new spatial policy in England. Regional Stud. 42 (5), 737-751. https://doi.org/10.1080/ 00343400701543280.

Rees, P., 2015. London needs homes, not towers of 'safe-deposit boxes'. The Guardian available at https://www.theguardian.com/commentisfree/2015/jan/25/plannersmust-take-back-control-of-london.

Rogers, D., Koh, S.Y., 2017. The globalisation of real estate: the politics and practice of foreign real estate investment. Int. J. Housing Policy 17 (1), 1-14. https://doi.org/10. 1080/19491247.2016.1270618.

Rogers, Dallas, Lee, Chyi Lin, Yan, Ding, 2015. The politics of foreign investment in Australian housing: Chinese investors. Translocal Sales Agents Local Resist. Hous. Stud. 30 (5), 730-748. https://doi.org/10.1080/02673037.2015.1006185.

Rogers, D., Wong, A., Nelson, J., 2017. Public perceptions of foreign and Chinese real estate investment: intercultural relations in Global Sydney. Aust. Geogr. 48 (4), 437-455. https://doi.org/10.1080/00049182.2017.1317050.

Sadiq Khan and London Labour, 2016. A Manifesto for all Londoners available at: http:// london.laboursites.org/wp-content/uploads/sites/5/2018/02/x160668_Sadiq_Khan_ Manifesto.pdf.

Savage, M., Williams, K., 2008. Elites: remembered in capitalism and forgotten by social sciences. Sociol. Rev. 56 (s1), 1-24. https://doi.org/10.1111/j.1467-954X.2008. 00759.x.

Savage, M., Bagnall, G., Longhurst, B., 2004. Globalisation and Belonging. Sage Publications, London.

Savage, M., 2014. Cultural capital and elective belonging: a British case study. In: Social Capital, Social Identities. De Gruyter, Berlin, Boston. https://doi.org/10.1515/ 9783110292930.29.

Savills, 2013. Spotlight: the World in London 2013 available at: https://pdf.euro.savills. co.uk/residential—other/spot-worldlondon-lr.pdf.

Simone, A., 2018. Improvising Lives: Afterlives of an Urban South Polity.

Stillerman, J., 2017. Housing pathways, elective belonging, and family ties in middle class Chileans' housing choices. Poetics. https://doi.org/10.1016/j.poetic.2017.01. 005.

Taylor, C., 2002. Modern social imaginaries. Public Culture 14, 91-124.

The Financial Times, 2016. Chinese keep buying London property despite Brexit. Available at: https://www.ft.com/content/40a42390-c857-11e6-90437e34c07b46ef (accessed 3 September 2019).

Tomaney, J., 2015. Region and place II: Belonging. Prog. Hum. Geogr. 39 (4), 507-516. https://doi.org/10.1177/0309132514539210.

Vertovec, S., 2012. Diversity and the social imaginary. Eur. J. Sociol. 53, 287-312. 